GLOBAL JOURNAL OF SOCIAL SCIENCES VOL 19, 2020: 1-11 COPYRIGHT@ BACHUDO SCIENCE CO. LTD PRINTED IN NIGERIA. ISSN 1596-6216 www.globaljournalseries.com; Info@globaljournalseries.com

\title{
THE IMPLICATIONS OF OIL THEFT ON SOCIAL AND ECONOMIC DEVELOPMENT IN THE NIGER DELTA.
}

TITILAYO SOREMI

(Received 26 April 2019, Revision Accepted 5 August 2019)

\begin{abstract}
The emergence of the exploration of crude oil in the Niger Delta area of Nigeria, has awarded the region worldwide renown as the economic backbone of the country, but also as a conflict flashpoint. Drawing from the propositions of the resource curse theory, the paper identifies Nigeria's rentier state structure as the underlining cause linked to the citing of conflict and corruption, as the reasons for the occurrence of oil theft in the Niger Delta. Also, the Dutch disease is identified as an economic explanation of the resource curse theory, and this is used to identify the economic implications of oil theft in the Niger Delta at the national level. In addition, the rentier state structure is used to identify the social implications of the occurrence of oil theft at the local level in the Niger Delta region. The paper posits that economic implications include reduced revenue, increased unemployment, and diversification of the economy. The social implications also include sustained conflict, curbed social development, and displacement of persons. To combat the illegal practice of oil theft, it is recommended that transparency and accountability should be adhered to in the relations among government, oil-producing communities and multinational corporations.
\end{abstract}

KEYWORDS: Niger Delta, oil theft, resource curse, sustainable development, security and conflict

\section{INTRODUCTION}

Crude oil is one of the main sources for world energy supply (Wu and Chen, 2019). Nigeria has a large deposit of crude oil, with proven reserves of 28.2billion barrels, making it one of the largest oil producers in Africa (Reuters, 2014; Elwerfelli and Benhin, 2018). Crude oil was discovered in Nigeria in 1956 and the first commercial oil well was drilled in Oloibiri, a town located in Bayelsa state, in the Niger Delta. The region currently houses oil fields, comprising 355 located onshore and 251 offshore (NNPC, 2019). Although crude oil has been discovered in other parts of Nigeria, such as Lagos state (Premium Times, 2016), and oil wells have been drilled in the Chad Basin, the
Niger Delta is currently the sole destination for commercial production of crude oil in Nigeria. As such, the oil extracted from the Niger Delta accounts for practically all of Nigeria's oil exports (NNPC, 2010).

The relevance of the Niger Delta to Nigeria cannot be over-emphasized. It is the metaphorical goose that lays the golden egg. This is because more than $75 \%$ of the country's national income is generated from oil exports (OPEC, 2019). Also, the quality of the different types crude oil found in the region makes it attractive for exploration by foreign investors, as they are characterised by low sulphur content, low salt composition and low soil to water ratio (Dickson and Udoessien, 2012).

Titilayo Soremi, School of Public Policy and Administration, York University, Canada 
These qualities make the crude oil easy to transport through pipelines and have informed tagging the crude oil sourced from the Niger Delta, light sweet crude oil blends. In addition, the oil production activities in the region necessitates the location of foreign and local oil companies in the region, therefore providing accommodation to drilling equipments, transportation fleets, and technological devices, that aid the extraction of crude oil from land or sea within and bothering the Niger Delta.

Despite the significance of oil production in the Niger Delta, the region grapples with the challenge of oil theft, in addition to poor living conditions in many oil-producing communities (Ebegbulem et al., 2013). This paper therefore aims to identify the reason why oil is being stolen in the Niger Delta, assess its economic and social impacts and propose how its incidence can be reduced. The first part gives an overview of the occurrence of oil theft in the Niger Delta and presents the resource curse theory which will be employed in discussing the core issues addressed in this paper. The second part highlights the cause, impacts and solutions to oil theft in the Niger Delta, and then leads to the concluding section where the key points raised in the paper are summarized and further recommendation on importance of citizen action is proposed.

\section{OIL THEFT IN THE NIGER DELTA}

The occurrence of oil theft in the Niger Delta started around late 1970 s to early 1980 s, when the country was predominantly under military rule. It was carried out under the command of top military personnel for the purpose of enriching themselves and forcefully maintaining political stability (Katsouris and Sayne, 2013). The illegal activity however, took a new turn with the advent of agitation for resource control by Niger Delta indigenes and the emergence of youth militancy (Ikelegbe, 2005; Katsouris and Sayne, 2013). At the outset of the agitations in the Niger Delta, the objective was primarily political with the citizens of the region demanding for an increase in the derivation fund (a specific percentage of oil rents accrued to the federal government), but when the government was unable to meet all their demands, many of the youths in the community took up arms against the government and engaged in criminal activities such as kidnapping, destruction of oil facilities, oil theft and sea piracy (Ikelegbe, 2005; Katsouris and Sayne, 2013). According to lkelegbe (2005), the involvement of youth groups in oil theft were at first limited to providing security for oil thieves, an activity from which they were able to enrich themselves and acquire weapons, but after a while they were able to engage in oil theft autonomously and this led to escalation of the illegal activity in the region.

Oil theft, which is also referred to as oil bunkering (Watts, 2007) occurs in three different modes in the Niger Delta (Katsouris and Sayne, 2013). The first mode involves locally confined activities in which oil is siphoned from pipelines that had been punctured or cut with a hacksaw, and the oil collected is then refined crudely and sold within the community (Asuni, 2009). In the second mode, oil thieves attach plastic hoses to wellheads or manifold points to divert the oil directly into barges, ships or canoes (Ikelegbe, 2005) after which the oil is transported through the 'Niger Delta's dense network of creeks, swamps and estuaries' (Katsouris and Sayne, 2013:3) and offloaded into tankers often anchored at the mouths of coastal rivers. When these tankers have been filled, the oil is transferred into other large tankers or mother ships in the high seas (Ikelegbe, 2005). The third mode which has also been termed the "white collar branch of oil theft' (Katsouris and Sayne, 2013:4) involves lifting of excess crude oil by extraction license holders and falsification of bill of lading records to cover up the actual quantity of oil being shipped out of the country.

In recent times, various studies have directed the attention of the academic community and the world at large, to the issue of oil theft in the Niger Delta. Ngada and Bower (2018) study the correlation between incidence of oil theft and poverty levels in local government areas where pipelines are located and find that there is limited correlation between these components. They however, observed a correlation between the increase in international market prices and increase in recorded cases of oil theft in the Niger Delta region. This finding calls for the examination of the international dimension to the cases of oil theft, and the investigation of its local impact on the Niger Delta region. Akpomera (2015) also reiterate the international link that sustains the illegal activity, and how it perpetrates a political economy that is criminal-inclined. This involves the militarisation of oil thieves through the supply of sophisticated weapons carried across the sea, by international buyers of stolen oil. On the other hand, Yeeles and Akporiaye (2016) suggest that there is an exaggeration of the cumulative extent and effects of oil theft. Their study finds that oil theft plays limited role in the national levels of production, international 
price of oil, and the related income generated from oil sales. They infer that the outcry is an unfounded threat, and the use of a doomsday scenario to tell the story of an impending 'oil crisis' is shown to be an embellishment of the situation. This finding differs from that of Ngada and Bower (2018). It may be explained by the difference in the focus on the ways in which crude oil if stolen in the Niger Delta. While Ngada and Bower (2018) consider three major ways of oil theft in the Niger Delta, Yeeles and Akporiaye (2016) direct their attention to only one of these three means i.e. pipeline siphoning. Importantly, Yeeles and Akporiaye (2016) note that the emphasis on local oil thieves is a distraction from underlying issues of structuring Nigeria as a rentier state, whereby the economy is heavily dependent on export returns from mineral extraction. In this instance, the rentier structure highlights Nigeria's substantial dependence on receipt of oil rents from international buyers of oil commodities. Njoku (2016) reiterate this position and emphasize the influence of the dependence on an oil economy that is not dominantly controlled and operated by local actors. In addition, Adibe et al (2018) also apply the notion of a rentier state to explain the increase in incidence of oil theft and the disenfranchisement of the citizens resident in oil-producing states. Altogether, there is a consensus on the importance of studying the occurrence of oil theft in the Nigeria Delta and analyzing its harmful effects on the drive for international investment, but more importantly, examining its debilitating impacts on the people of the Niger Delta.

This paper focuses on the implications of oil theft on the social and economic development of the Niger Delta. It addresses a gap in the literature by applying a theoretical approach to identifying common causality in the different reasons explaining the occurrence of oil theft in the Niger Delta. Through the application of the resource curse theory, the paper also addresse show oil theft exacerbates threatening conditions in the Niger Delta and diminishes the likelihood of attaining substantial development goals for the indigenes of the oil-producing communities. The next section presents the resource theory and discusses the aspects of the theory that will be utilised for the analysis of the implications of oil theft on social and economic development of the Niger Delta.

\section{THEORETICAL FRAMEWORK}

The theoretical framework that will be used to discuss the issues addressed in this paper is the 'resource curse' theory. The theory posits that developing countries that are rich in natural mineral resources and are dependent on the export of their natural resources, experience slower economic growth rate than developing countries that are resource-poor (Badeeb et al., 2017; Soremi, 2013). The term 'resource curse' was first introduced by Auty (1994) and may have gained acclaim as a result of a 1995 paper by Sachs and Warner titled 'Natural resource abundance and economic growth'. Resource curse has also been applied to specific natural resources like oil in published works of other scholars such as 'The Paradox of Plenty: Oil Booms and Petro-States' by Karl (1997) and 'The Oil Curse: How Petroleum Wealth Shapes the Development of Nations oil curse' by Ross (2012).

The expectation of economic growth and the subsequent disappointing performance of many developing countries rich in oil can serve as a good example to illustrate the resource curse theory. In the 1950s and 1960s, there was an expectation that returns from oil exports will lead to prosperity in less developed countries oilproducing countries (Ross, 2012). A 1979 quote credited to the president of one of such countries, Venezuela, in his comment on what the country could achieve as an oil-rich state also signify the anticipation of economic growth -

"One day........Americans will be driving cars with bumpers made from bauxite, our aluminum, and our labor. And we will be a developed country like you" (Karl, 1997:4).

Unfortunately, Venezuela alongside some of the other oil-rich developing countries like, Iran, Angola and Nigeria, after years of exporting their oil are today characterized by 'poor economic growth, vulnerability to price shocks, poverty, and high inequality, as well as high levels of corruption, authoritarianism, and poor governance' (Kennedy, 2014:264). Weighing the words in the quote above against the current realities in these countries helps in a way to give evidence to the resource curse theory. Beyond economic implication, resource curse has also been associated with greater incidence of violence and civil conflict that are often inflamed by struggle for control of the resources and citizens' outrage at the economic and institutional outlooks of the states (Watts 2004; Ross 2012).

There are varying explanations for the paradox in which resource-rich countries experience slow growth rate and the prominent ones are i) the rentier state structure of the countries and ii) the Dutch disease (Badeeb et al., 2017). A rentier 
state is one that derives most of its revenue from external sources (Ross, 1999). The term rentier is derived from the ensuing activity of paying rents for use of landed property. Rents are paid by extractive companies and remitted to the authority designated as owner of the rights to the property. In the context of oil production in Nigeria and many other developing countries, whereby the extraction of crude oil is an activity dominated by international interests, the collection of rents often represents an earning opportunity that is devoid of significant local labour input. As such, income is not generated on the grounds of working the land, but on the basis of loaning it out. According to the resource curse theory, a rentier economy will prompt a rentseeking behaviour. This is because the accumulation of funds earned from export of mineral resources boosts the coffers of the resource-rich countries, and this can lead to an earnest quest for creative avenues to expend the bounty. This behaviour can be demonstrated by leaders in the countries and can lead to the emergence of governments that are inept in formulating development strategies and selfserving hegemonic elite whose interest is in rent seeking (Chaudhry, 1989; Omeje, 2007). It can also be exhibited by citizens, with increased abandon of previous labour roles and entrepreneurship ventures, in pursuit of opportunities in extractive sector. This is synonymous with the Nigerian parlance of getting 'a share of the national cake'.

Dutch disease on the other hand refers to a situation whereby increase in real exchange rate of the resource-exporting country due to the revenue from oil, makes the country's non-oil export products less competitive and less attractive to investors (Otaha, 2012). The phenomenon was identified when the economy of the previously manufacturing town of Groningenin the Netherlands transformed to a natural gas-mining enclave (Babeeb et al., 2017). The introduction of mining activities in the town thus led to the rapid decline of manufacturing industries. The term Dutch disease was coined to explain what led to the deindustrialization (Bjorvatnnhh et al., 2012). The explanations for getting inflicted with the Dutch disease are primarily economic. They include the increase in the exchange rate of the resource-rich country leading to increased cost of non-mineral products, making the sector unattractive to investors. Another explanation is the flight of revenues to other countries where the mining companies originate from, such that the resource-rich country is not receiving the full rewards attributable to the extraction of the minerals in its territory.

It should be noted that not all developing countries involved in oil production have been victims of the resource curse. Countries such as the United Arab Emirates and Sultanate of Brunei are examples of oil- rich developing countries that have been able to escape the phenomenon (Ezirim, 2011). However, despite these exceptions, the theory can still serve a valuable purpose in deciphering the link between resource-rich developing countries and the seeming attendant slow economic growth prevalent in some of these countries. In addition, it can help to proffer solutions to countries that are experiencing the phenomenon and also serve as guide to developing countries that have suddenly discovered they are resource-rich. The next section draws from the resource curse theory to identify underling causation for the occurrence of oil theft in the Niger Delta.

\section{WHY DOES OIL THEFT OCCUR IN THE NIGER DELTA?}

The incidence of crude oil theft in oil-producing communities is not peculiar to the Niger Delta. In the 1980s, there were reported cases of oil theft in Texas, USA (Telegraph, 1981). Countries like Indonesia and Mexico are also presently confronting this challenge (The Economist, 2012; Jakarta Globe, 2013). However, Nigeria leads the pack with a record of upto300,000 barrels of oil being stolen daily, as against 1,000 bpd in Indonesia (Jakarta Globe, 2013) and 10,000bpd in Mexico (Reuters, 2013). Due to this enormous quantity of oil that is illegally siphoned from the Niger Delta, Nigeria is recognized as a hotspot for oil theft (The Economist, 2012).

In the case of the three other countries mentioned above i.e. USA, Indonesia and Mexico, the major reasons that have been given for the incidence of oil theft include loose security measures and sheer criminality. Oil theft in Texas, USA was directly linked to not locking crude oil tanks that are waiting to be transported (Telegraph, 1981). In Indonesia, it was linked to ease of siphoning oil from aging pipelines that are planted above the surface (Jakarta Globe, 2013) and in Mexico, it was noted to be an extended activity of the existing criminal network in the country (Flinn, 2016). The reasons for the occurrence of oil theft in the Niger Delta however, appears to be webbed in grim complexity. Some authors have identified oil theft as an integral part of the economy of conflict in the Niger Delta 
region (Ezirim, 2011; Obi, 2010; Ikelegbe, 2005 and Watts, 2007). Others have linked it to the corrupt practices of government officials (Katsouris and Sayne, 2013 and Asuni, 2009). Based on the different reasons identified, this paper will draw from the resource curse theory to determine a likely common causation that underpins these different reasons.

The first point that will be discussed is the situation of oil theft as part of the conflict in the Niger Delta. Ikelegbe (2005) and Obi (2010) note that oil bunkering is a key activity of militant youths in the Niger Delta, who launch attacks against the government of Nigeria and multinational corporations (MNCs) in their fight for resource control. Emergence of youth militancy in the Niger Delta has been linked to non-violent struggles that spread through the oilproducing communities in the late 1970s through the 1980s against the deplorable living conditions in the region and decrease in the derivation fund from $50 \%$ of oil rents and royalties to $1.5 \%(\mathrm{Obi}$, 2010). Sadly, from what began as a political uprising, Niger Delta militant youths are now known for "economic and financial criminal activities including pipeline vandalization, piracy, oil bunkering, small arms proliferation, hostagetaking and kidnapping' (Ezirim, 2011:62). Ikelegbe (2008) gives a classification of the militants into three groups namely insurgent, deviant insurgent, and criminal armed, and identified the third group as those responsible for oil theft in the Niger Delta region. The 'criminal armed' groups are led by warlords and with their engagement in illegal oil bunkering and other illicit economic activities, the warlords gained access to funds with which they acquired weapons, built camps, strengthened their membership (Obi, 2010) and were able to operate with or without the support of political patrons (Watts, 2007). Thus, it can be said that oil theft occurs in the Niger Delta as part of the violent escalation of the political agitation of the people of the Niger Delta and it persists as a financial mechanism for established criminal groups. Also, a basis for the political struggle in the region can be singled out as the neglect of development activities and inequitable fund allocation by the Nigerian government. Basedau and Lay (2009) note that countries experiencing the resource curse have the characteristic of selective distribution of rents. Katsouris and Sayne (2013) also attest that funds that could be used for developmental projects may be diverted to non-productive areas in a rentier state. Hence, a possible basis for the conflict in the Niger Delta that has led to stealing of oil in the region can be said to be the rentier state structure of Nigeria.

The second major reason that has been identified in the literature for occurrence of oil theft in the Niger Delta is corruption. Asuni (2009) describes the existence of corruption in the Niger Delta and in Nigeria as an endemic one that has enveloped many law enforcement officials, government personnel and politicians. Katsouris and Sayne (2013) also confirm the involvement of these officials in oil theft in the Niger Delta. Top Nigerian officials cut their teeth in the oil theft business during military rule. Over time, evidence surfaced that corrupt members of the security forces were actively involved. The country's return to democracy in 1999 then gave some civilian officials and political 'godfathers' more access to stolen oil (Katsouris and Sayne, 2013:2). To explain the incentives that may have driven corrupt officials to engage in oil theft, Katsouris and Sayne (2013) report that the proceeds from the illegal activity is used to fund election campaigns and carry out atrocities such as targeted killings, buying votes or paying thugs to disrupt election processes. They also mention that the corrupt officials fund these atrocities for the purpose of remaining in power and securing continued access to oil rents.

In summary, the rentier state structure of Nigeria can be identified as a common basis for the identification of conflict and corruption, as the key reasons for oil theft in the Niger Delta. This position aligns with the findings in other studies such as Adibe et al. (2018) and Soremi (2013). The observation is also linked to the substantial international influence of MNCs in a rentier state, whereby the corporations aim to procure favours of political leaders, rather than carefully cultivating a mutually-beneficial relationship with the local populace. The government's dominant dependence on externally accrued large-scale revenue, also directs the attention and affection of political leaders to MNCs instead of the local populace. As a result, a rentier state structure is often festooned with corruption, authoritarianism and rent seeking (Duruigbo, 2009; DiJohn; Basedau and Lay, 2009). The quest for preserving the status quo of a rentier state, through the unhindered collection of oil rents, also prevents the will and determination to quell the illegal activity, therefore leaving the scare of a vicious cycle in its wake. 
4. ECONOMIC AND SOCIAL IMPACTS OF OIL THEFT IN THE NIGER DELTA

This section highlights the economic and social implications of oil theft in the Niger Delta. It draws from the propositions of the resource curse theory to identify the different impacts and structure the discussion. According to scholars, the rentier state thesis of the resource curse theory is politically inclined and have social implications, while the Dutch disease thesis is economically driven and have financial implications (Bandeep et al., 2017; Fleming et al., 2015). Furthermore, the suitability of the application of these aspects of the resource curse theory have been shown to differ at particular levels of governance, such that the economic explanation is very relevant to the national level of government and the political dimension is more applicable to a sub-national level (Aragon and Rud, 2013; Fleming et al., 2015). As such, this paper follows the approach of linking the economic aspect of the resource curse theory to the financial impact at the national level (Nigeria), and the political aspect to the social impact at the subnational level (Niger Delta region).

\section{ECONOMIC IMPLICATIONS OF OIL THEFT IN THE NIGER DELTA}

Reduced revenue for all layers of government: As typical of most developing countries that are victims of the resource curse, the Dutch disease plays out in Nigeria's economy. Since its involvement in oil exportation, there has been near collapse of the non-oil sectors and in particular, the agricultural sector, which in the past contributed the bulk of Nigeria's export earnings (Otaha, 2012). Today, the country is heavily dependent on sale of crude oil, such that $80 \%$ of federal government's revenue, $95 \%$ of export receipts and $90 \%$ of foreign exchange earnings come from oil exports. Also, based on the system of fiscal federalism operational in the country, the federal government distributes the returns from oil exports to the other layers of government i.e. the state and local governments, and these allocations account for $82 \%$ of the funds available to them (Ahmad and Singh, 2003). A country that is so heavily dependent on returns from sale of crude oil will be affected by any increase or decrease in the quantity of oil being sold through the government.

Diversification of Nigeria's Economy: Loss of revenue may be seen as a negative impact; however, it may also lead to diversification of Nigeria's economy. Loss of revenue may lead the government to pay more attention to nonextractive industries and embark on taxation programs that are appropriately monitored. Already, there are slight indications of this effort based on a news report that non-oil sectors were the main drivers of Nigeria's economic growth in recent times (This Day, 2014). Although this development has not been directly linked to loss of revenue from oil theft in the Niger Delta, the IMF in its report on the growth of the non-oil sector in Nigeria notes that oil's contribution to the GDP has shrunk by $1.3 \%$ (Oxford Business Group, 2014). If this trend of growth in the non-oil sector persists, which is a way to overcome the Dutch disease, it may help reduce government's dependence on oil and possibly contribute to a process that can help Nigeria escape the resource curse.

Increase in rate of unemployment: In addition to its impact on revenue, oil theft in Niger delta has led most of the prominent MNCs operating in Nigeria including Shell, Chevron and ENI to exit from many of their onshore ventures (Bloomberg, 2013). ENI in particular had initially planned a complete pull out from the country before it later reneged on its intention (Ventures Africa, 2014). It is believed that this development, even though some of these companies have commenced new operations offshore (Bloomberg, 2013), may bring about massive job cuts in the country (Daily Trust, 2014), thereby demonstrating the volatility of mineral-dependent economy. The job cuts ensuing from dramatic change in operations of MNCs can therefore lead to an increase in rate of unemployment and a possible decrease in income available to households.

\section{SOCIAL IMPACTS OF OIL THEFT IN THE NIGER DELTA}

Sustained conflict: As noted by Obi (2010), proceeds from oil theft are often used by warlords in the Niger Delta to acquire weapons and also to recruit and train fighters. These acquisitions and reinforcements provide the 'criminal armed' groups with the resources they need to perpetuate their engagement in the illegal activity. In a bid to sustain the receipt of oil rents, the federal government sought to rid the Niger Delta of criminality and deployed military troops to the region. The militarization of the region has led to occasional face-offs between the criminals and the military with casualties reported on both 
sides. Apart from the face-offs with the military, 'criminal armed' groups also engage in armed hostilities among themselves over distribution of appropriated resources and alleged collaboration with security agencies (Ikelegbe, 2005). The protracted state of conflict and restiveness in the Niger Delta threatens to shatter the peace, security and integrity of the region (Agbiboa, 2014).

Impediment to social development: The quest for sustaining the country's rentier state structure also sustains conflict in the Niger Delta, and impedes provision of social amenities in the area, due to limited assurance of security for government's social development agencies and nongovernmental organisations. Also, young people of school age may choose to join the 'criminal armed' gangs rather than remain in school just so that they can acquire wealth from engaging in oil theft and this may lead to increase in number of out-of-school youths. This may also result in loss of manpower for credible development of the community, as the youths may lose their lives in clashes with the military or other criminal groups or even end up in prisons.

Internal population displacement: Another social impact of oil theft in the Niger Delta is internal population displacement of the people of the Niger Delta based on clashes between the military and 'criminal armed' groups, conflict among the criminal groups, and lower levels of household income as a result of contaminated farmlands and rivers. The displacement has led many families to migrate from their communities to other riverine oil-producing communities in search of productive fishing grounds or to urban cities across the country to live in slums and secure menial jobs (Ebegbulem et al., 2013).

The economic and social impacts highlighted above cut across not only the national government of Nigeria, but also the other layers of government in the country, Niger Delta indigenes, and international corporations. This shows that the impact of oil theft in the Niger Delta is far reaching and needs to be addressed. Based on this, the next section proposes solutions that can curb the incidence of this activity.

5. What may be done to reduce the occurrence of oil theft in the Niger Delta?

At first glance, the description of how oil thieves operate in the Niger Delta may immediately prompt the proposition of solutions that might only address the apparent superficial issues such as inadequate security or low employment rates in the region. However, focusing on these concerns may result in proffering only temporary relief or possibly complicate the situation like it did in the past. Some examples of such temporary measures include militarization of the region and amnesty programme, which may have even triggered a new surge in occurrence of the activity (ESRC, 2012; Aghedo, 2013; Agbiboa, 2014). As a result, this section will again, draw from the resource curse theory to address the underlining cause identified for occurrence of oil theft in the Niger Delta i.e. the rentier state structure of Nigeria.

Two major themes appear in literatures that focus on how resource-rich developing countries can escape the resource curse namely based on addressing the challenge of their rentier state structure namely i) good Institutions and ii) transparency and accountability (Ross, 2012; 2014). While the latter theme has been more widely expounded by scholars such as Luong and Weinthal (2010), and Kolstad and Wiig (2017), the case for emphasizing the importance of good institutions however still requires more clarification on how institutions should be improving (Lawera et al., 2017; Stevens and Dietsche, 2008). This paper's proposition on how oil theft in the Niger Delta will therefore focus on transparency and accountability.

The relevant bodies that are affected by and can influence oil production in the Niger Delta (particularly the different layers of government, MNCs, community groups and international bodies) should be encouraged and if possible compelled to be transparent and accountable in their modes of operation as this will help ensure that they give thorough consideration to the implication of their words and actions. The different aspects in which transparency and accountability should be enforced and how the intervention can result in reduced occurrence of oil theft are discussed below-

Oil production records, revenues, government allocations and expenditure: With adherence to transparency and accountability, local communities might have more confidence in the government and therefore agree to share security-aiding information that can lead to capturing the criminals in the region. For instance, the installation of a satellite as a proffered solution for curbing oil theft may be critiqued, as this decision made by the Department of Petroleum Resources (DPR) does not seem to be community-inclined, and neither does it appear to follow a disclosure procedure that allows the cost of the contract to be made public (Reuters, 2019). In particular, if the 
Nigerian government is able to gain the confidence of Niger Delta activists and indigenes, there will be less agitation and oil thieves will have less opportunity to take advantage of a genuine social movement for executing and justifying their disreputable actions.

Operation of MNCs and plight of host Niger Delta communities: Accurate information on the operations of MNCs in the Niger Delta and the social status of the people living in the community, might make the home countries of MNCs to pressure the corporations to rethink the exploitative approach to production of oil from the Niger Delta. Home countries of MNCs can also ensure that the business partnership between the Nigerian government and the MNCs yield actual development benefits to Niger Delta indigenes and with improvement in the standard of living, oil theft might become a less attractive vocation.

Publication of criminal records: With regards to the alleged direct involvement of the military and elites in oil theft, if information on the people caughtin the process is made public, this will probably be followed by a demand for justice by Nigerians citizens and international activists. This action can lead to conviction and sentencing of the culprits, which in effect will deter other elites from venturing into oil theft. Transparent criminal records will also dissuade the government from awarding security contracts to militants (Adibe et al., 2018), as this practice pose a challenge of double jeopardy whereby criminals are not prosecuted and the conflict situation in the region can be exacerbated with the militants' access to funds and weapons.

Election and governance processes: Transparency and accountability can also help guarantee that election processes are free and fair and devoid of manipulation. Credible elections will lead to emergence of competent leaders, who will not extol political demands over economic priorities, but can facilitate diversification of the economy and commit to improving social wellbeing in the Niger Delta. As a result, there will be improved living conditions in the Niger Delta and less people might be lured into becoming oil thieves.

\section{CONCLUSION}

With the low standard of living in many oilproducing communities, the Niger delta exemplifies the resource curse in Nigeria. Apart from being an oil producing region that is largely underdeveloped and the Niger Delta is also infamously known for oil theft. This paper applied the resource curse theory to explain the cause of oil theft in the Niger Delta. It also highlighted the economic and social implications of the activity. In addition, it proposed the adoption of transparency and accountability, as measures for combatting oil bunkering. While it must be recognised that there are ongoing international efforts in this direction, notably, the establishment of the Extractive Industries Transparency Initiative (EITI), and followed up with governmentbacked local action through the setup of a Nigerian arm of the initiative, NEITI, it cannot be overlooked that there are yet endemic challenges plaguing the extraction of crude oil in the Niger Delta. This calls for extended action that will strengthen the work of NEITI. Importantly, Nigerian citizens, and particularly all Niger Delta indigenes need to be empowered to be aware of their rights, acquire the knowledge and skill for monitoring elected and appointed government officials, and be comfortable with questioning the actions of the officials, without resorting to rentseeking themselves. In a similar vein, based on EITI's assertion that the ownership of a country's natural resources lies with the citizens, local professional bodies like the Society of Petroleum Engineers (SPE), can also be officially empowered to halt operations of MNCs to ensure they adhere to ethical standards of transparency and accountability.

Beyond oil theft, environmental challenges and quest for energy security by oil-importing countries, do pose a threat to Nigeria's status as an oil-dependent nation. While these threats can deprive Nigeria of potential earnings from oil exports, they can also help to slowly ease the country out of its rentier state structure. As a nonrentier state, the government will likely have no option but to rely on citizens' taxes for its funds, and in turn, the citizens will become more proactive in monitoring how the funds are expended. With this structural change, Nigeria may become devoid of non-admirable attributes that foster criminal activities (such as corruption, rent seeking and authoritarianism) and oil theft in the Niger Delta might be successfully curtailed.

\section{REFERENCES}

Adibe, R., Nwagwu, E. and Albert, O., 2018. Rentierism and Security Privatisation in the Nigerian Petroleum Industry: Assessment of Oil Pipeline Surveillance and Protection Contracts. Review of African Political Economy 45(156): 345353. 
Agbiboa, D.E., 2014. Amnesty at Risk: Is the Niger Delta Sliding Back into Instability? Conflict Trends 1:50-56.

Akpomera, E., 2015. International Crude Oil Theft: Elite Predatory Tendencies in Nigeria. Review of African Political Economy, 42(143): 156-165.

Aragon, F.M. and Rud, J. P. (2013). Natural resources and local communities: evidence from a Peruvian gold mine, American Economic Journal: Economic Policy 5(2): 1- 25.

Asuni, J. B., 2009, Blood Oil in the Niger Delta, United States Institute of Peace, Washington DC, USA.

Auty, R. M., 1994, Industrial Policy Reform in Six Large Newly Industrializing Countries: The Resource Curse Thesis, World Development 22(1): 11-26.

Badeeb, R. A., Hooi Lean, H.H. and Clark, J., 2017. The Evolution of the Natural Resource Curse Thesis: A Critical Literature Survey. Resources Policy 51: 123-134.

Bloomberg 2013, Shell to Chevron Move Offshore as Nigerian Risks Mount, July 31, https://www.bloomberg.com/news/article s/2013-07-30/shell-flees-to-nigerianoffshore-fields-amid-onshore-woes [Accessed April 17, 2019].

Daily Trust, 2014. Oil Coys' Divestment May Lead to Massive Job Cuts, January 24 https://www.dailytrust.com.ng/oil-coysdivestment-may-lead-to-massive-jobcuts.html [Accessed April 17, 2014].

Dickson, U. J. and Udoessien, E. I., 2012. Physicochemical Studies of Nigeria's Crude Oil Blends. Petroleum and Coal 54(3): 243-251.

Ebegbulem, J. C., Ekpe, D. and Adejumo, T. O., 2013. Oil Exploration and Poverty in the Niger Delta Region of Nigeria: A Critical Analysis. International Journal of Business and Social Science 4(3): 279287.
Elwerfelli, A. and Benhin, J., 2018. Oil a Blessing or Curse: A Comparative Assessment of Nigeria, Norway and the United Arab Emirates, Theoretical Economics Letters 8: 1136-1160.

Ezirim, G. E., 2011. Resource governance and conflict in the Niger Delta: Implications for the Gulf of Guinea Region, African Journal of Political Science and International Relations 5(2): 61-71.

Fleming, D. A., Measham, T. G. and Paredes, D., 2015. Understanding the resource curse (or blessing) across national and regional scales: Theory, empirical challenges and an application. Agricultural and Resource Economics 59(4): 624-639.

Flinn, C. M. 2016. Black gold in the black market: Tackling the issue of international oil smuggling through technology, public policy, and internal corporate controls. Texas International Law Journal 51: 119 143.

Ikelegbe, A, 2005. The Economy of Conflict in the Oil Rich Niger Delta Region of Nigeria, Nordic Journal of African Studies 14(2): 208-234.

Ikelegbe, A., 2008. Popular and Criminal Violence as Instruments of Struggle: The Case of Youth Militia in the Niger Delta Region, NAIIPRIO Workshop on Violent Conflict in the Niger Delta, August 18-19, Oslo, Norway.

Jensen, N. and Wantchekon, L., 2004, Resource Wealth and Political Regimes in Africa, Comparative Political Studies 37(7): 816.

Karl, T. L., 1997. The Paradox of Plenty: Oil Booms and Petro-States, University of California Press, Berkeley, USA.

Katsouris, C. and Sayne, A., 2013. Nigeria's Criminal Crude: International Options to Combat the Export of Stolen Oil, Chatham House, London, UK.

Kennedy, E., 2014. From Petro-States to New Realities: Perspectives on the Geographies of Oil, Geography Compass 8(4): 262-276. 
Kjetil Bjorvatnnhh, K., Farzanegan, M. R. and Schneider, F., 2012. Resource Curse and Power Balance: Evidence from OilRich Countries. World Development 40(7): 1308-1316.

Kolstad, I. and Wiig, A. 2017. Diversification and Democracy. International Political Science Review 39(4): 551-569.

Kolstad, I. and Wiig, A., 2009. Is Transparency the Key to Reducing Corruption in Resource-Rich Countries?, World Development 37(3): 521-532.

Lawera, E. T., Lukas, M.C. and Jørgensen, S. H., 2017. The Neglected Role of Local Institutions in the 'Resource Curse' Debate. Limestone Mining in the Krobo Region of Ghana. Resources Policy 54: 43-52.

Lenning, E. and Brightman, S., 2009. Oil, Rape and State Crime in Nigeria, Critical Criminology 17(1): 35-48.

Luong, P. J, and Weinthal, E., 2010. Oil is not a curse: Ownership structure and institutions in Soviet successor states. New York: Cambridge University Press.

Ngada, T. and Bower, K. 2018. Spatial and Temporal Analysis of Crude Oil Theft in the Niger delta. Security Journal, 31(2): 501-523.

Njoku, A. O., 2016. Oil Pipelines Vandalism and its Effects on the Socio-Economic Development in Nigerian Society. International Journal of Multidisciplinary Academic Research 4(4): 2309-3218.

NNPC, 2019. History of the Nigerian Petroleum Industry, http://www.nnpcgroup.com/NNPCBusiness/BusinessInformation/Pages/Industry-History.aspx [Accessed April 17, 2019].

Obi, C.I., 2010. Oil Extraction, Dispossession, Resistance, and Conflict in Nigeria's OilRich Niger Delta, Canadian Journal of Development 30(1-2): 219-236.
OPEC, 2019. Nigeria facts and figures. https://www.opec.org/opec web/en/about _us/167.htm [Accessed July 17, 2019].

Opukri, C. O. and Ibaba, I. S., 2008. Oil induced environmental degradation and internal population displacement in the Nigeria"s Niger Delta, Journal of Sustainable Development in Africa 10(1): 173-193.

Otaha, J. I., 2012, Dutch Disease and Nigeria Oil Economy, Africa Research Review 6(1): 82-90.

Premium Times 2016 Nigeria: Lagos Now Officially an Oil-Producing State Governor Ambode. May 16, https://allafrica.com/stories/20160517000 3.html [Accessed April 11, 2016].

References for oil theft paper

Reuters, 2013. Mexico's Pemex says losing up to $10,000 \mathrm{bpd}$ to oil theft, June 6, http://www.reuters.com/article/2013/06/0 6/mexico-pemex-theftsidUSL1N0EI1GL20130606[Accessed April 17, 2019].

Reuters, 2014. Update 1-Shell says Nigerian oil theft costs billions, March 13, http://www.reuters.com/article/2014/03/1 3/shell-strategy-nigeriaidUSL6NOMA28T20140313[Accessed April 17, 2019].

Reuters, 2019. Nigeria Deploys Satellite Tech to Track Oil Smugglers. https://www.reuters.com/article/usnigeria-oil-theft/nigeria-deploys-satellitetech-to-track-oil-smugglersidUSKCN1S61KG [Accessed July 23, 2019].

Robinson, J. A., Torvik, R. and Verdier, T., 2006. Political foundations of the resource curse, Journal of Development Economics 79(2): 447-468.

Ross, M. L., 1999. The Political Economy of the Resource Curse, World Politics 51(2): 297-322. 
Ross, M. L., 2012. The Oil Curse: How Petroleum Wealth Shapes the Development of Nations, Princeton University Press, Oxfordshire, UK.

Ross, M. L., 2014. What have we learned about the resource curse?, Working Paper, University of California, Los Angeles, USA.

Sachs, J. D. and Warner, A. M., 1995. Natural resource abundance and economic growth, NBER Working Paper No. 5398, National Bureau of Economic Research, Cambridge, Massachusetts, USA.

Soremi, T., 2013. Oil Theft in the Niger Delta: Why Does it Occur, What are its Economic and Social Impacts and What may be Done to Reduce it? University of Sussex, Brighton.

Stevens, P. and Dietsche, E., 2008. Resource Curse: An Analysis of Causes, Experiences and Possible Ways
Forward, Energy Policy 36(1): 56-65.

This Day, 2014. Non-oil Sector Drives Nigeria"s GDP Growth, February 3, https://allafrica.com/stories/20140203065 6.html[Accessed April 17, 2019].

Watts, M., 2004. Resource Curse? Governmentality, Oil and Power in the Niger Delta, Nigeria, Geopolitics 9(1): 5080.

Watts, M., 2007. Petro-Insurgency or Criminal Syndicate? Conflict and Violence in the Niger Delta, Review of African Political Economy 34(114): 637-660.

Wu, X. F. and Chen, G. Q., 2019. Global overview of crude oil use: From source to sink through inter-regional trade. Energy Policy, 128: 476-486

Yeeles, A. and Akporiaye, A., 2016. Risk and Resilience in the Nigerian Oil Sector: The Economic Effects of Pipeline Sabotage and Theft. Energy Policy 88: 187-196. 